\title{
Dialogue between Staphylococcus aureus SA15 and Lactococcus garvieae strains experiencing oxidative stress
}

Clothilde Queiroux, Muriel Bonnet, Taous Saraoui, Pierre Delpech, Philippe Veisseire, Etienne Rifa, Cécile Moussard, Geneviève Gagne, Céline Delbès ${ }^{*+}$ (I) and Stéphanie Bornes ${ }^{\dagger}$

\begin{abstract}
Background: Staphylococcus aureus is an important foodborne pathogen. Lactococcus garvieae is a lactic acid bacterium found in dairy products; some of its strains are able to inhibit $\mathrm{S}$. aureus growth by producing $\mathrm{H}_{2} \mathrm{O}_{2}$. Three strains of $L$. garvieae from different origins were tested for their ability to inhibit $\mathrm{S}$. aureus SA15 growth. Two conditions were tested, one in which $\mathrm{H}_{2} \mathrm{O}_{2}$ was produced (high aeration) and another one in which it was not detected (low aeration). Several $\mathrm{S}$. aureus genes related to stress, $\mathrm{H}_{2} \mathrm{O}_{2}$-response and virulence were examined in order to compare their level of expression depending on the inoculated L. garvieae strain. Simultaneous L. garvieae $\mathrm{H}_{2} \mathrm{O}_{2}$ metabolism gene expression was followed.
\end{abstract}

Results: The results showed that under high aeration condition, L. garvieae strains producing $\mathrm{H}_{2} \mathrm{O}_{2}$ ( $\mathrm{N} 201$ and CL-1183) inhibited S. aureus SA15 growth and impaired its ability to deal with hydrogen peroxide by repressing $\mathrm{H}_{2} \mathrm{O}_{2}$-degrading genes. L. garvieae strains induced overexpression of $S$. aureus stress-response genes while cell division genes and virulence genes were repressed. A catalase treatment partially or completely restored the SA15 growth. In addition, the $\mathrm{H}_{2} \mathrm{O}_{2}$ non-producing L. garvieae strain (Lg2) did not cause any growth inhibition. The SA15 stress-response genes were down-regulated and cell division genes expression was not affected. Under low aeration condition, while none of the strains tested exhibited $\mathrm{H}_{2} \mathrm{O}_{2}$-production, the 3 L. garvieae strains inhibited S. aureus SA15 growth, but to a lesser extent than under high aeration condition.

Conclusion: Taken together, these results suggest a L. garvieae strain-specific anti-staphylococcal mechanism and an $\mathrm{H}_{2} \mathrm{O}_{2}$ involvement in at least two of the tested L. garvieae strains.

Keywords: Lactococcus garvieae, Staphylococcus aureus, Antimicrobial, Hydrogen peroxide, Gene expression

\section{Background}

Staphylococcus aureus is an opportunistic human pathogen that can be responsible for food poisoning [1]. Its pathogenic activity is due to the production of various enzymes and toxins. It can be found in different environments including milk and dairy products [2]. In cheese, its level should not exceed $10^{5} \mathrm{CFU} . \mathrm{g}^{-1}$ (European Community Regulation No. 852-853/2004).

Lactococcus garvieae is an ubiquitous LAB (Lactic Acid Bacteria) that can be found in various fermented foods including dairy products $[3,4]$, in fish, ruminant or human

\footnotetext{
*Correspondence: celine.delbes@inra.fr

${ }^{\dagger}$ Céline Delbès and Stéphanie Bornes contributed equally to this work.

Université Clermont Auvergne, INRA, UMRF, F-15000 Aurillac, France
}

microbiota [5] and can be associated with pathologies such as fish lactococcoses [6, 7]. LABs such as Lactococcus lactis or Lactococcus garvieae are able to inhibit the proliferation of pathogens in cheese by the production of hydrogen peroxide [8], bacteriocins [9], by competition for nutrients $[10,11]$ or by acidification of the medium [12-14]. Depending on its concentration, hydrogen peroxide has a bactericide or a bacteriostatic effect on S. aureus [15]. $L$. garvieae raises our interest because a specific dairy strain of this LAB, N201 strain, can inhibit $S$. aureus growth by the production of $\mathrm{H}_{2} \mathrm{O}_{2}$ [2, 16, 17]. Moreover, it has a strong technological potential as a ferment for cheese production [18] and has almost no effect on acidification of the medium, compared to other LABs [2]. The inhibitive

(c) The Author(s). 2018 Open Access This article is distributed under the terms of the Creative Commons Attribution 4.0 International License (http://creativecommons.org/licenses/by/4.0/), which permits unrestricted use, distribution, and 
properties of L. garvieae N201 were confirmed on 2 strains of S. aureus: a human pathogenic strain, MW2 [19] and a non-pathogenic dairy strain, SA15, isolated from Saint-Nectaire cheese [17]. Delpech et al. [20] showed that $S$. aureus had no effect on $L$. garvieae growth and $\mathrm{H}_{2} \mathrm{O}_{2}$-related gene expression. On the contrary, L. garvieae N201 impaired the capacity of both strains of $S$. aureus to deal with the presence of $\mathrm{H}_{2} \mathrm{O}_{2}$ which led to growth deficiency $[2,16,17]$.

In order to investigate the interaction between $S$. aureus and L. garvieae in oxidative stress-inducing culture conditions, genes involved in $\mathrm{H}_{2} \mathrm{O}_{2}$ metabolism were first choice targets, whose expression has been monitored by Delpech et al. $[17,20]$ in co-cultures of $L$. garvieae N201 and S. aureus SA15 or MW2.

In L. garvieae, superoxide dismutase $\operatorname{sodA}[21,22]$ and pyruvate oxidase pox $\mathrm{B}$ genes $[23,24]$ are involved in $\mathrm{H}_{2} \mathrm{O}_{2}$ synthesis. As they do not have any catalase, LAB generally degrade $\mathrm{H}_{2} \mathrm{O}_{2}$ using alkyl hydroxyperoxidase (Ahp) [25] or glutathione peroxidase (Gpx) [26]. Thioredoxine reductase $(\operatorname{Trx})$ are involved in response to Reactive Oxygen Species (ROS) [27, 28].

In $S$. aureus, Catalase (KatA) and Alkyl hydroxyperoxidase (Ahp) play a role in $\mathrm{H}_{2} \mathrm{O}_{2}$ degradation $[29,30]$. Ahp leads to a dual function in oxidative-stress resistance, environmental persistence and host-pathogen interaction [29]. Amongst the targeted genes, dnaK is known to be involved in $\mathrm{H}_{2} \mathrm{O}_{2}$-resistance [31, 32], $\operatorname{clpC}$ has an important role in oxidative stress regulation, and $c t s \mathrm{R}$ is a transcriptional repressor of stress-genes [33]. Moreover, the 2 latter genes, belonging to the $d c w$ cluster involved in cellular division, might be modulated by $\mathrm{H}_{2} \mathrm{O}_{2}$-stress, leading to $\mathrm{S}$. aureus growth impairment [34]. So, if LAB can modify this genes cluster expression, it could have an inhibiting effect on cellular division.

In addition to $S$. aureus growth modulation, L. garvieae may also have an effect on its virulence. Enterotoxins are the main toxins responsible for $S$. aureus food poisoning. Ninety-four per cent of $S$. aureus isolated from cow milk have at least one enterotoxin-encoding gene [35]. Amongst the different enterotoxins, enterotoxin C, encoded by sec4 gene, is the most frequently involved in food poisoning [36-39]. Cretenet et al. [40] showed that this virulence-related gene expression can be modified by L. lactis in cheese. S. aureus virulence is under control of the agr system which is involved in regulating many stress response and virulence genes [41-43]. agrA is a response regulator [44] and is able to induce hld, a $\delta$-lysin gene [43], and enterotoxin C encoding gene sec4 [45]. The agr system itself is controlled by several molecular intermediates such as SaeRS and SrrAB. SaeRS is a two-component system involved in response to environmental stress which could inhibit agr system [46] and also control virulence genes $[47-50]$. SrrAB is also a two-component system activated in an anaerobic environment [51]. It would be involved in virulence gene control [52] in response to $\mathrm{H}_{2} \mathrm{O}_{2}$. Indeed, in the presence of $\mathrm{H}_{2} \mathrm{O}_{2}$, srrA is repressed in $\mathrm{S}$. aureus [53]. Under anaerobic conditions, SrrA represses agrA and hld expression [54, 55]. CodY, a regulatory protein involved in repressing virulence gene expression in S. aureus, is also involved in controlling $a g r$ system and virulence genes [56].

The level of aeration can change the level of $\mathrm{H}_{2} \mathrm{O}_{2}$-production according to the LAB strain. Indeed, it has been demonstrated that the transcriptomes of L. lactis and L. garvieae are significantly modified by the aeration level [20,57]. Lactobacillus crispatus can produce $\mathrm{H}_{2} \mathrm{O}_{2}$ in high aeration conditions but not in static conditions [58]. Contrariwise, Lactobacillus delbrueckii subsp. bulgaricus can also produce $\mathrm{H}_{2} \mathrm{O}_{2}$ in static conditions, even though the amount produced is lower than in high aeration conditions [59].

The aim of the present study was to compare the transcriptional response involved in the antagonistic interaction between $S$. aureus and different strains of $L$. garvieae. In addition to N201 strain isolated from raw milk Saint-Nectaire cheese and already well described [2, 16], two other L. garvieae strains were selected for their different capacities to produce $\mathrm{H}_{2} \mathrm{O}_{2}:$ a $\mathrm{H}_{2} \mathrm{O}_{2}$-producing strain, CL-1183 (VIVASET, Veterinary Faculty, Complutense University from Madrid) isolated in Brazil from the milk from buffalo cows affected by subclinical mastitis [5] as well as a $\mathrm{H}_{2} \mathrm{O}_{2}$-non producing strain, Lg2, a fish pathogenic strain isolated in Japan [60]. The expression of $S$. aureus genes related to oxygen metabolism, response to stress, cell division and virulence was measured as well as the expression of $L$. garvieae genes related to oxygen metabolism.

\section{Results}

In order to investigate the interaction between $S$. aureus and L. garvieae in oxidative stress-inducing culture conditions, we followed the growth of the strains and measured the amount of $\mathrm{H}_{2} \mathrm{O}_{2}$ in two culture conditions i.e. under high and low aeration levels. The genes whose expression has been monitored by Delpech et al. $[17,20]$ were chosen to compare the transcriptional response involved in the antagonistic interaction between $S$. aureus and different strains of $L$. garvieae. The expression of $S$. aureus genes related to oxygen metabolism, response to stress, cell division and virulence was measured as well as the expression of $L$. garvieae genes related to oxygen metabolism (Table 1).

\section{Ability of $L$. garvieae strains to produce $\mathrm{H}_{2} \mathrm{O}_{2}$ and to inhibit S. aureus growth}

The effect of aeration level on microbial growth was tested by determining cellular concentrations of both 
Table 1 Differentially expressed Staphylococcus aureus genes in co-culture with 3 Lactococcus garvieae strains (N201, CJ-1183 and Lg2), summary table

\begin{tabular}{|c|c|c|c|c|c|c|c|c|c|}
\hline \multirow[b]{2}{*}{ Genes } & \multicolumn{3}{|l|}{$6 \mathrm{~h}$} & \multicolumn{3}{|l|}{$9 \mathrm{~h}$} & \multicolumn{3}{|l|}{$24 \mathrm{~h}$} \\
\hline & N201 & CL-1183 & $\operatorname{Lg} 2$ & N201 & CL-1183 & Lg2 & N201 & $C L-1183$ & Lg2 \\
\hline \multicolumn{10}{|l|}{ High aeration } \\
\hline Up-regulated & - & dnak & - & $\begin{array}{l}\text { clpC } \\
\text { cstR } \\
\text { dnak } \\
\text { agrA }\end{array}$ & agrA & - & - & - & - \\
\hline Down-regulated & $\begin{array}{l}\text { sodA } \\
\text { mraW }\end{array}$ & $\begin{array}{l}\text { ahpF } \\
\text { katA } \\
\text { mraw } \\
\text { codY }\end{array}$ & - & $\begin{array}{l}\text { katA } \\
\text { sodA } \\
\text { mraW } \\
\text { srrA }\end{array}$ & $\begin{array}{l}\text { katA } \\
\text { mraw } \\
\text { srrA }\end{array}$ & - & $\begin{array}{l}\text { katA } \\
\text { sodA } \\
\text { codY } \\
\text { saes } \\
\text { sec4 }\end{array}$ & $\begin{array}{l}\text { ahpF } \\
\text { sodA } \\
\text { sec4 }\end{array}$ & $\begin{array}{l}\text { ahpF } \\
\text { clpC } \\
\text { dnaK } \\
\text { agrA } \\
\text { codY } \\
\text { hld }\end{array}$ \\
\hline \multicolumn{10}{|l|}{ Low aeration } \\
\hline Up-regulated & - & - & - & $\begin{array}{l}\text { agrA } \\
\sec 4\end{array}$ & $\begin{array}{l}\text { ahpF } \\
\text { agrA } \\
\text { sec4 } \\
\text { sel2 }\end{array}$ & $\begin{array}{l}\text { clpC } \\
\text { cstR } \\
\text { dnak }\end{array}$ & - & $\operatorname{cod} Y$ & $\operatorname{agrA}$ \\
\hline Down-regulated & $\sec 4$ & $\operatorname{cod} Y$ & - & - & - & $\operatorname{cod} Y$ & - & - & $\begin{array}{l}\text { sodA } \\
\text { srrA }\end{array}$ \\
\hline
\end{tabular}

For detailed values, see Additional files 2 and 3

microorganisms. In pure culture, $S$. aureus growth was almost identical under both high and low aeration conditions. However, the population count reached at $24 \mathrm{~h}$ was $1.2 \log \mathrm{CFU} / \mathrm{ml}$ lower under low aeration than under high aeration (Fig. 1a). The 3 different strains of L. garvieae grew as well under high aeration level as under low aeration level independent of the presence of S. aureus (Additional file 1). $\mathrm{pH}$ values remained stable $(7.0 \pm 0.2)$ in all cultures over the whole experiment (data not shown).

Detectable amounts of $\mathrm{H}_{2} \mathrm{O}_{2}$ were produced exclusively under high aeration level by N201 and CL-1183

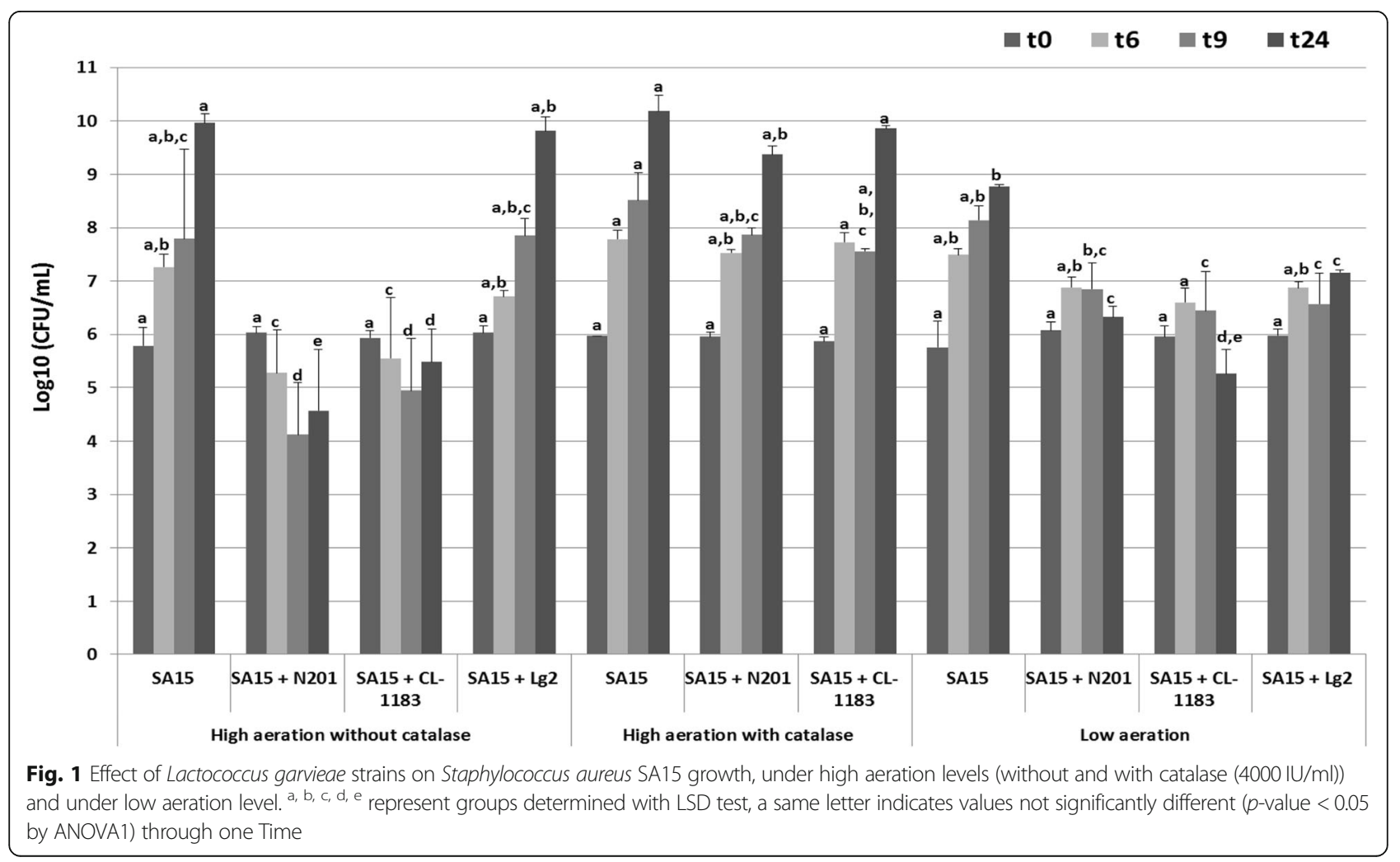


strains in co-culture with SA15. N201 strain produced from $1.327 \mathrm{mM} \pm 0.09$ to $1.517 \mathrm{mM} \pm 0.18$ of $\mathrm{H}_{2} \mathrm{O}_{2}$. The strain CL-1183 produced slightly more $\mathrm{H}_{2} \mathrm{O}_{2}$ than the strain $\mathrm{N} 201$, from $1.663 \mathrm{mM} \pm 0.23$ to $2.415 \mathrm{mM} \pm 0.34$. While N201 $\mathrm{H}_{2} \mathrm{O}_{2}$-production peak was at $9 \mathrm{~h}, \mathrm{CL}-1183$ $\mathrm{H}_{2} \mathrm{O}_{2}$-production stayed stable after $9 \mathrm{~h}$ (Table 2).

Under high aeration, when co-cultivated with N201, SA15 growth was $2.1 \log$ [CFU.ml ${ }^{-1}$ ] lower than in pure culture as early as $6 \mathrm{~h}$ with a maximal growth inhibition of $5.8 \mathrm{log}$ [CFU.ml ${ }^{-1}$ ] at $24 \mathrm{~h}$. SA15 growth co-cultivated with CL-1183 was $1.7 \log \left[\mathrm{CFU} \cdot \mathrm{ml}^{-1}\right.$ ] lower compared to pure culture as early as $6 \mathrm{~h}$. The maximal growth inhibition was observed after $24 \mathrm{~h}$ of co-culture $(4.5 \mathrm{log}$ [CFU.ml ${ }^{-1}$ ] lower). SA15 co-cultivated with Lg2 did not show any significant impairment in growth throughout the experiment compared to pure culture (Fig. 1a).

Under low aeration level and in co-culture with N201, CL-1183 or Lg2, SA15 growth was lower than in pure culture as early as $6 \mathrm{~h}\left(0.6 \log \left[\mathrm{CFU} \cdot \mathrm{ml}^{-1}\right], 0.9 \log \left[\mathrm{CFU} \cdot \mathrm{ml}^{-1}\right.\right.$ ] or $0.6 \log \left[\mathrm{CFU} \cdot \mathrm{ml}^{-1}\right]$, with a maximal growth inhibition at $24 \mathrm{~h}\left(2.5 \log \left[\mathrm{CFU} \cdot \mathrm{ml}^{-1}\right], 3.5 \mathrm{log}\left[\mathrm{CFU} \cdot \mathrm{ml}^{-1}\right.\right.$ or $1.6 \mathrm{log}$ [CFU.ml $\left.{ }^{-1}\right]$ ], respectively) (Fig. 1a).

To determine the involvement of $\mathrm{H}_{2} \mathrm{O}_{2}$ produced by N201 and CL-1183 in growth inhibition of SA15, co-cultures of SA15 with these 2 strains were performed under high aeration level in presence of catalase (Fig. 1). No detectable amount of $\mathrm{H}_{2} \mathrm{O}_{2}$ was observed at any time. S. aureus cell concentration was not significantly different in presence of catalase compared to control (Fig. 1) during both exponential and stationary phases. Statistical analysis, using ANOVA, showed that in presence of catalase there was no significant difference of SA15 count after $24 \mathrm{~h}$ in co-culture with CL-1183 compared to pure culture. In contrary, SA15 cell concentration in co-culture SA15/N201 was still $0.8 \mathrm{log}$ $\left[\mathrm{CFU} \cdot \mathrm{ml}^{-1}\right.$ ] lower than in pure culture. These results showed that the inhibition of SA15 growth by N201 and CL-1183 was partially or completely suppressed by catalase.

Table $2 \mathrm{H}_{2} \mathrm{O}_{2}$ concentration produced by Lactococcus garvieae in pure culture and in co-culture with Staphylococcus aureus SA15, under high aeration

\begin{tabular}{lllll}
\hline \multicolumn{5}{l}{ Hydrogen peroxide concentration $(\mathrm{mM})$} \\
\hline Time $(\mathrm{h})$ & 0 & 6 & 9 & 24 \\
SA15 & $\mathrm{ND}$ & $\mathrm{ND}$ & $\mathrm{ND}$ & $\mathrm{ND}$ \\
$\mathrm{SA} 15+\mathrm{N} 201$ & $\mathrm{ND}$ & $1.343 \pm 0.141$ & $1.517 \pm 0.180$ & $1.327 \pm 0.090$ \\
$\mathrm{SA15}+\mathrm{CL}-1183$ & $\mathrm{ND}$ & $1.663 \pm 0.230$ & $2.415 \pm 0.340$ & $2.409 \pm 0.240$ \\
SA15 + Lg2 & $\mathrm{ND}$ & $\mathrm{ND}$ & $\mathrm{ND}$ & $\mathrm{ND}$ \\
$\mathrm{N} 201$ & $\mathrm{ND}$ & $1.455 \pm 0.027$ & $1.549 \pm 0.040$ & $1.105 \pm 0.030$ \\
CL-1183 & $\mathrm{ND}$ & $1.257 \pm 0.010$ & $1.317 \pm 0.030$ & $1.148 \pm 0.058$ \\
Lg2 & $\mathrm{ND}$ & $\mathrm{ND}$ & $\mathrm{ND}$ & $\mathrm{ND}$ \\
\hline ND not dected & & & &
\end{tabular}

ND not detected
Effect of L. garvieae strains on S. aureus genes expression under high aeration level (Additional file 2)

Whatever the L. garvieae strain cultivated with SA15, none of the $\mathrm{H}_{2} \mathrm{O}_{2}$-response genes tested was up-regulated. When SA15 was cultivated with L. garvieae N201 or CL-1183, katA was down-regulated, at $9 \mathrm{~h}$ and $24 \mathrm{~h}$ with N201 (3.7 and 3.0-times, respectively), or at 6 and $9 \mathrm{~h}$ with CL-1183 (3.9 and 3.2-times, respectively). When cultivated with N201, ahpF expression in SA15 was not modified in comparison with pure culture, whereas in co-cultures SA15/CL-1183 and SA15/Lg2, it was down-regulated (2.1-times at $6 \mathrm{~h}$ and 2.9-times at $24 \mathrm{~h}, 6.9$-times at $24 \mathrm{~h}$, respectively). sodA was down-regulated at 6, 9 and $24 \mathrm{~h}$ in co-cultures with N201 (2.2, 4.4 and 3.9-times, respectively) or at 24 h (2.2-times) with CL-1183. No change in expression of katA and sodA was observed with Lg2.

L. garvieae N201 induced an up-regulation of the three SA15 stress-response genes tested at $9 \mathrm{~h} ; c l p C, c t s \mathrm{R}$ and dnaK were 2.0-times, 3.7-times and 2.5-times more expressed than in pure culture, respectively. When cultivated with CL-1183, only dnaK was 2.8 -times up-regulated at $6 \mathrm{~h}$, while $c l p \mathrm{C}$ and $c t s \mathrm{R}$ expressions were not affected. Conversely, in co-culture SA15/Lg2, $c l p C$ and $d n a \mathrm{~K}$ were 3.9-times and 19.8-times down-regulated respectively, while $c t s \mathrm{R}$ did not show any significant difference in its expression.

In both SA15/N201 and SA15/CL-1183 co-cultures, $m r a W$ cell division gene was strongly down-regulated at 6 and $9 \mathrm{~h}$ (7.0-times and 20.3-times, and 20.0-times and 12.0-times, respectively). In co-culture SA15/Lg2, mraW expression was not affected.

In co-culture, the five SA15 virulence-related regulator genes tested displayed contrasted patterns of expression. At $9 \mathrm{~h}$, in both SA15/N201 and SA15/CL-1183 co-cultures, agrA was up-regulated (4.0-times with N201 and 3.4-times with CL-1183), while srrA was down-regulated (7.1-times or 6.4-times with $\mathrm{N} 201$ or CL-1183 respectively). $\operatorname{cod} \mathrm{Y}$ expression was down-regulated 4.1-times at $24 \mathrm{~h}$ by $\mathrm{N} 201$ and 3.6-times at $6 \mathrm{~h}$ by CL-1183. saeS expression was 2.4-times lower at $24 \mathrm{~h}$ in co-culture with N201 than in pure culture, whereas it was not affected by CL-1183. hld expression remained stable until $24 \mathrm{~h}$ when SA15 was in co-culture with N201 or CL-1183. In co-culture SA15/Lg2, at $24 \mathrm{~h}, \operatorname{agrA}, \operatorname{cod} \mathrm{Y}$ and hld expressions were all down-regulated (3.0-times, 2.6-times and 3.9-times, respectively), while saeS and srrA expressions remained stable.

In co-cultures SA15/N201 and SA15/CL-1183, amongst the 2 enterotoxins-encoding genes tested, only sec 4 expression was modified at $24 \mathrm{~h}$, with a 4.1 -times and a 9.0-times down-regulation, respectively. sel2 expression was not modified whatever the SA15 culture conditions were. In co-culture SA15/Lg2, no enterotoxin gene expression was affected. 
Effect of L. garvieae strains on S. aureus genes expression under low aeration level (Additional file 3)

Under low aeration level, in presence of CL-1183, the $\mathrm{H}_{2} \mathrm{O}_{2}$-response gene $a h p \mathrm{~F}$ was 4.2 -times up-regulated at $9 \mathrm{~h}$, whereas in presence of Lg2, $\operatorname{sodA}$ was 6.5-times down-regulated at $24 \mathrm{~h}$. All the stress-response genes tested were up-regulated at $9 \mathrm{~h}$ (3.4-times for $c l p \mathrm{C}$, 4.0-times for ctsR and 2.1-times for dnaK) with Lg2. No change in stress-response genes expression was observed when SA15 was cultivated with N201 or CL-1183. Concerning the cell division gene $m r a W$, its expression was not modified, whatever the strain cultivated with SA15.

Amongst virulence-related regulator genes, agrA was up-regulated in all three co-cultures at different stages of growth. It was the only virulence-related regulator gene differentially regulated by N201 (6.0-times up-regulated at $9 \mathrm{~h})$. In the same way, this gene was 4.1-times up-regulated at $9 \mathrm{~h}$ by CL-1183, and 2.5-times up-regulated at $24 \mathrm{~h}$ by Lg2. $\operatorname{cod} \mathrm{Y}$ was 2.0-times down-regulated at $6 \mathrm{~h}$ but 2.0-times up-regulated at $24 \mathrm{~h}$ with CL-1183, while codY and srrA were 2.1- and 2.7-times down-regulated at 9 and $24 \mathrm{~h}$, respectively with Lg2.

The enterotoxin gene sec 4 was up-regulated in both N201/SA15 and CL-1183/SA15 co-cultures, (3.5- and 2.7-times, at 6 and $9 \mathrm{~h}$ respectively, with N201, and 2.5-times at $9 \mathrm{~h}$ with CL-1183). sel2 was 3.5-times up-regulated at $9 \mathrm{~h}$ only in the presence of CL-1183.

\section{Effect of aeration on L. garvieae strains (Additional file 4)}

To evaluate the strain-specific effect of aeration on $L$. garvieae, expression of $5 \mathrm{H}_{2} \mathrm{O}_{2}$-related genes of them $(\operatorname{tr} x \mathrm{~B} 1, \operatorname{ahp} \mathrm{C}, g p x, p o x \mathrm{~B}$ and $\operatorname{sod} \mathrm{A})$ was monitored and compared between the $3 \mathrm{~L}$. garvieae strains in co-culture with SA15. Overall, most differential expressions concerned $\mathrm{H}_{2} \mathrm{O}_{2}$-degradation genes. Differences between $\mathrm{H}_{2} \mathrm{O}_{2}$-producing and non-producing strains were essentially related to $a h p C$ : both N201 and CL-1183 overexpressed this gene under low aeration (5.6-times at $24 \mathrm{~h}$ in N201, 4.0-times at $6 \mathrm{~h}$ and 6.5-times at $9 \mathrm{~h}$ in CL-1183). Conversely, Lg2 overexpressed $a h p C$ (4.7-times) at $9 \mathrm{~h}$ under high level of aeration. Both CL-1183 and Lg2 overexpressed trxB1 under high level of aeration (2.9-times at $6 \mathrm{~h}$ in CL-1183 and 2.1-times $24 \mathrm{~h}$ in Lg2). Amongst $\mathrm{H}_{2} \mathrm{O}_{2}$-synthesis genes, only $\mathrm{CL}-1183$ overexpressed poxB (4.1-times at $9 \mathrm{~h}$ under low aeration).

\section{Discussion}

The aim of the study was to compare the transcriptional response involved in the antagonistic interaction between $S$. aureus and different strains of $L$. garvieae. Three strains of $L$. garvieae from different origins were used: N201, a dairy-isolated strain known to be a $S$. aureus inhibiting strain; CL-1183, a strain isolated from milk from buffalo cows suffering from mastitis; and Lg2, a fish pathogenic strain. Under high aeration condition, two of them were shown to be able to produce detectable amount of $\mathrm{H}_{2} \mathrm{O}_{2}$ (N201 and CL-1183), whereas the third one (Lg2) was not.

\section{L. garvieae strains and aeration level effect on $S$. aureus SA15 growth and on $\mathrm{H}_{2} \mathrm{O}_{2}$ - and stress-responses}

Under high aeration level, only L. garvieae N201 and CL-1183 inhibited $S$. aureus growth. CL-1183 down-regulated $S$. aureus $\mathrm{H}_{2} \mathrm{O}_{2}$-degradation genes $(a h p \mathrm{~F}$ and katA) and N201 and Lg2 only down-regulated katA or $a h p F$ respectively. This could mean that SA15 lost its ability to deal with $\mathrm{H}_{2} \mathrm{O}_{2}$-stress and suggest that the $\mathrm{H}_{2} \mathrm{O}_{2}$ detoxification occurred predominantly via KatA. These results are in accordance with those obtained by Cosgrove et al. [29], showing that $S$. aureus ahpC-katA mutant was no more sensitive to $\mathrm{H}_{2} \mathrm{O}_{2}$ than the katA mutant. They also found out that, Ahp would have less affinity for $\mathrm{H}_{2} \mathrm{O}_{2}$ than KatA and that it could be an alternative solution for $\mathrm{H}_{2} \mathrm{O}_{2}$-degradation when KatA was not functional. In our study, despite N201 only down-regulated katA and not $a h p \mathrm{~F}$, AhpF did not play its compensatory role in $\mathrm{H}_{2} \mathrm{O}_{2}$ detoxification. This result can be explained by the fact that KatA was responsible for detoxifying high levels of $\mathrm{H}_{2} \mathrm{O}_{2}$, whereas $\mathrm{AhpC}$ was responsible for the removal of low levels of $\mathrm{H}_{2} \mathrm{O}_{2}$ [29]. This could be correlated with the large amounts of $\mathrm{H}_{2} \mathrm{O}_{2}$ detected in the co-cultures SA15/N201. The down-regulation of katA, at $9 \mathrm{~h}$ and $24 \mathrm{~h}$, can be explained by the fact that $\operatorname{srr} \mathrm{A}$ was also down regulated. Mashruwala and Boyd [61] found that srrAB mutant strain had decreased transcription of genes encoding for $\mathrm{H}_{2} \mathrm{O}_{2}$ resistance factors as katA. They also reported that SrrAB positively influenced $\mathrm{H}_{2} \mathrm{O}_{2}$ resistance during periods of high $\mathrm{O}_{2}$ dependent respiratory activity, but not when cellular respiration was diminished as a result of lower $\mathrm{O}_{2}$ availability. $S$. aureus SA15 genes involved in stress-response $(c l p \mathrm{C}, c t s \mathrm{R}, d n a \mathrm{~K})$ were all up-regulated by N201 and only $d n a \mathrm{~K}$ was up-regulated by CL-1183, whereas $\operatorname{clpC}$ and $d n a \mathrm{~K}$ were down-regulated by $\mathrm{Lg} 2$. These results indicated that in presence N201 and CL-1183, SA15 detected an oxidative stress as a result of $\mathrm{H}_{2} \mathrm{O}_{2}$ production by these two $L$. garvieae strains. However, the up-regulation of these genes did not allow SA15 to fight against this stress, although precedent studies reported that $S$. aureus $\operatorname{clpC}$ or dnaK mutants growth was impaired in the presence of $\mathrm{H}_{2} \mathrm{O}_{2}$ stress $[32,62,63]$ and that a basic level of expression of $d n a \mathrm{~K}$ was sufficient in response to this stress [32]. All these data highlighted the complexity of the stress response machinery and the important role of $c l p C, c t s \mathrm{R}$ and dnaK genes. Moreover, while mraW gene was not 
differentially expressed in presence of Lg2, it was repressed at 6 and $9 \mathrm{~h}$ by N201, confirming results obtained by Delpech et al. [17], and by CL-1183 in our study, when S. aureus growth was inhibited. The repression of $m r a W$ by N201 and CL-1183 was positively correlated with inhibition of SA15 growth. These results are supported by Cretenet et al. [40] showing that L. lactis was able to inhibit fts $\mathrm{H}, f t s \mathrm{~L}$ and $f t s \mathrm{Z}$ genes also involved in cellular division. Interestingly, several studies reported that inhibition of cell division protein is a promising approach for anti-staphylococcal therapy $[64,65]$.

Catalase treatment partially reduced SA15 growth inhibition by N201, confirming the result obtained by Delbes-Paus et al. [2], whereas the inhibition by CL-1183 was completely suppressed. Oogai et al. [66] observed that in presence of catalase, the $S$. aureus MW2 growth inhibition by Streptococcus sanguinis was completely suppressed. These observations confirmed the role of $\mathrm{H}_{2} \mathrm{O}_{2}$ produced by LAB in growth inhibition of $S$. aureus. Our study demonstrated that under high level of aeration, the inhibition of $S$. aureus by L. garvieae involved strain specific mechanisms. Indeed, CL-1183 inhibited SA15 growth mainly by $\mathrm{H}_{2} \mathrm{O}_{2}$ production whereas inhibition due to $\mathrm{N} 201$ may involve the combined action of $\mathrm{H}_{2} \mathrm{O}_{2}$ and other antagonistic mechanism.

Under low aeration condition, S. aureus growth was almost identical to that measured under high aeration condition, except after $24 \mathrm{~h}$, when we observed a $1,2 \log$ reduction in the $S$. aureus population level that could be due to the depletion of oxygen. Ledala et al. [67] showed that the growth rate of $S$. aureus was independent of oxygen limitation over $12 \mathrm{~h}$ although its metabolome was significantly affected. S. aureus growth was slightly inhibited by the three $L$. garvieae strains, although none of them could produce detectable amounts of $\mathrm{H}_{2} \mathrm{O}_{2}$ (Fig. 1). This suggests that there was another inhibitory mechanism involved. These results match those obtained with N201 in the previous studies [2, 17, 20]. Delbes-Paus et al. [2] have shown that in milk, even if $\mathrm{H}_{2} \mathrm{O}_{2}$ was not detected, S. aureus growth was inhibited by L. garvieae N201. However, no clear hypothesis to explain the mechanism of the anti-staphylococcal activity under low aeration could be drawn from the gene expression data. However, the up-regulation of stress-response genes in the presence of Lg2 was observed. Indeed, $c l p C, c t s \mathrm{R}$ and $d n a \mathrm{~K}$ genes, were all up-regulated at $6 \mathrm{~h}$ in co-culture with Lg2, suggesting that Lg2 triggered a stress on SA15 which led to a growth inhibition.

\section{L. garvieae strains and aeration level effect on S. aureus SA15 virulence gene expression}

Under high level of aeration, L. garvieae N201 reduced $S$. aureus virulence-related genes expression confirming results obtained by Delpech et al. [17]. Cretenet et al. [40] and Queck et al. [68] have shown that the agr system, involved in the regulation of genes linked to $S$. aureus virulence, was repressed by L. lactis even if L. lactis does not produce $\mathrm{H}_{2} \mathrm{O}_{2}$ in this condition. Molecular intermediaries SaeRS and SrrAB are involved in controlling the agr system [46]. We showed srrA expression was repressed in co-culture with N201 and CL-1183, when $\mathrm{H}_{2} \mathrm{O}_{2}$ was produced as already observed by Chang et al. [53]. Moreover, Majerczyk et al. [56] have shown that a cod $\mathrm{Y}$ mutant could derepressed agr system. In our conditions, $\operatorname{cod} \mathrm{Y}$ was repressed by $\mathrm{CL}-1183$ at $6 \mathrm{~h}$ explaining $a g r \mathrm{~A}$ up-regulation at $9 \mathrm{~h}$, whereas repression of $\operatorname{cod} \mathrm{Y}$ at $24 \mathrm{~h}$ by Lg2 cannot explain agrA down-regulation suggesting that another regulator might be involved. Moreover, at $24 \mathrm{~h}$, despite SA15 growth was not modified, Lg2 caused a down-regulation of three virulence-related regulator genes tested in this study (agrA, $\operatorname{cod} \mathrm{Y}, h l d)$. sec 4 and sel2 are two enteroxin-encoding genes found in S. aureus SA15 [17]. Although enteroxin $\mathrm{C}$-encoding gene sec4 is under the control of the agr system [45], agrA expression was only induced by N201 and CL-1183 and sec4 was repressed under high aeration level as shown by Delpech et al. [17]. Our data showed the repression of virulence associated genes and of enterotoxin encoding genes as well as simultaneous $S$. aureus growth inhibition in the presence of N201 or CL-1183, indicating that these 2 strains not only inhibited SA15 growth but also potentially attenuated its virulence.

Under low aeration condition, S. aureus over-expressed agrA and enterotoxin-encoding genes sel2 and sec4 in presence of N201 and CL-1183, whereas Lg2 did not induce any modification. In presence of Lg2, agrA was up-regulated at $24 \mathrm{~h}$. This result can be explained by the fact that SA15 srrA gene was down-regulated, at the same time. The same observation was reported by Yarwood et al. [55]. They showed that transcription of RNAIII from the agr locus was inversely dependent on expression of srrAB. Inherently, despite SA15 agrA up-regulation by Lg2, no modification in enterotoxin genes expression was observed. Yarwood et al. [55] also reported that the SA15 $s r r \mathrm{~B}$ mutant growth was significantly slower in anaerobic condition, which is in accordance with SA15 growth inhibition in presence of $\mathrm{Lg} 2$.

\section{L. garvieae strain responses to low and high levels of aeration in co-culture with $S$. aureus SA15}

It seemed that the three strains of $L$. garvieae differed essentially in their ability to degrade $\mathrm{H}_{2} \mathrm{O}_{2}$. Presence of $\mathrm{H}_{2} \mathrm{O}_{2}$ would not depend only on $\mathrm{H}_{2} \mathrm{O}_{2}$-synthesis, but also on $\mathrm{H}_{2} \mathrm{O}_{2}$-degradation by L. garvieae strains, which is an original mechanism, and in accordance with the results obtained by Delpech et al. [20]. 
In high aeration level, Lg2 overexpressed two $\mathrm{H}_{2} \mathrm{O}_{2}$ degradation genes $a h p C$ and $t r x \mathrm{~B}$ at 9 and $24 \mathrm{~h}$ respectively. The non-detection of $\mathrm{H}_{2} \mathrm{O}_{2}$ could be explained by the absence of production of $\mathrm{H}_{2} \mathrm{O}_{2}$ or by its degradation by AhpC and TrxB. The latter mechanism could explain why, under low aeration, despite CL-1183 overexpressed an $\mathrm{H}_{2} \mathrm{O}_{2}$-synthesis gene, poxB, no detectable $\mathrm{H}_{2} \mathrm{O}_{2}$ was observed. Indeed, at the same time, this strain overexpressed the $\mathrm{H}_{2} \mathrm{O}_{2}$ degradation gene ahpC. Our data showed that the importance of the inhibition varies depending on the presence or absence of $\mathrm{H}_{2} \mathrm{O}_{2}$. Indeed, inhibition can occur while $\mathrm{H}_{2} \mathrm{O}_{2}$ is not detected. As regards other potential explanations for the growth inhibition, the only putative bacteriocin identified in the L. garvieae N201 genome was homologous to garvieaecin Q (GarQ, data not shown), a class IId bacteriocin [69]. In view of the results of previous experiments on L. garvieae N201 [20], the inhibition was probably caused neither by garvieaecin $\mathrm{Q}$ nor by a protein, nor by a lipid, and nor by a polysaccharide. In the present study, we evidenced $L$. garvieae strain-specific response in $S$. aureus gene expression which suggests that molecular mechanisms involved in the inhibition could differ between L. garvieae strains. Further investigations are needed to elucidate these mechanisms. A detailed analysis of strains physiology is needed to evaluate the potential role of nutritional competition in the inhibition. A global transcriptomic approach of the interaction would shed some light on the metabolic dialogue between these strains, and more particularly the potential involvement of quorum-sensing.

\section{Conclusions}

Our data evidenced an impact of the aeration condition on the interaction between SA15 and L. garvieae strains.

Under high level of aeration, only N201 and CL-1183 produced detectable amounts of $\mathrm{H}_{2} \mathrm{O}_{2}$ and consequently inhibited SA15 growth. Both L. garvieae strains activated SA15 stress-response genes and inhibited the expression of several genes involved in $\mathrm{H}_{2} \mathrm{O}_{2}$-degradation, virulence and cellular division. A catalase treatment partially or completely suppressed this inhibition and no $\mathrm{H}_{2} \mathrm{O}_{2}$ was detected. Lg2 strain did not produce any detectable amount of $\mathrm{H}_{2} \mathrm{O}_{2}$ and did not inhibit SA15 growth. However, as N201 and CL-1183, Lg2 inhibited SA15 virulence-related genes and stress-response related genes.

Under low aeration level, none of the L. garvieae strains produced any detectable amount of $\mathrm{H}_{2} \mathrm{O}_{2}$. N201 and CL-1183 were still able to inhibit SA15 growth, as well as, Lg2. While N201 and CL-1183 induced the up-regulation of the SA15 enterotoxin-encoding genes and related regulator agrA, Lg2 caused up-regulation of SA15 stress-related genes and down-regulated virulence-related regulators genes.
The antagonistic properties of L. garvieae against $S$. aureus were strain- and aeration level-dependent. Under high aeration, they involved $\mathrm{H}_{2} \mathrm{O}_{2}$ production by two out of the three L. garvieae tested strains. This study provides new insights into microbial interactions mechanisms and shows the importance of investigating strain-specific effects.

\section{Methods}

\section{Strains and culture conditions}

Strains Lactococcus garvieae N201, CL-1183 and Lg2 and Staphylococcus aureus SA15 were cultivated in Brain-Heart Infusion buffered to $\mathrm{pH} 7$ using Potassium Phosphate (BHI, Biokar Diagnostic, Pantin, France) at $30^{\circ} \mathrm{C}$ and $37^{\circ} \mathrm{C}$, respectively, under static condition. After $20 \mathrm{~h}$, cells were harvested at $3500 \mathrm{~g}$ during $15 \mathrm{~min}$. Cell pellets were resuspended in $2 \mathrm{ml}$ of BHI and syringed 5 times. Cell concentration was then determined using a Petroff-Hausser counting chamber. Fifty milliliters of buffered BHI, containing or not $4000 \mathrm{IU} \mathrm{ml}^{-1}$ of catalase from bovine liver (ref. C100, Sigma), were then co-inoculated at $\sim 10^{7}$ cells per ml for L. garvieae and $\sim 10^{6}$ cells per $\mathrm{ml}$ for $S$. aureus, or just with $L$. garvieae or $S$. aureus at the same concentration in $250 \mathrm{ml}$ Erlenmeyer flasks or in $50 \mathrm{ml}$ Falcon tubes, as described previously $[2,17]$.

Then, Erlenmeyer flasks were incubated for 6,9 or $24 \mathrm{~h}$ at $30^{\circ} \mathrm{C}$ under shaking condition $(150 \mathrm{rpm})$, corresponding to the high level of aeration condition. The low level of aeration condition corresponded to static fully filled 50 $\mathrm{ml}$ Falcon tubes. At 0, 6, 9 and $24 \mathrm{~h}, 1 \mathrm{ml}$ of the cultures was removed to be syringed and serially diluted in Ringer's solution. After adequate mixing, $100 \mu \mathrm{l}$ of each dilution were plated onto solid Baird Parker for S. aureus and BHI agar for L. garvieae for numeration. Colony-forming units were counted after overnight incubation at $37^{\circ} \mathrm{C}$ for $S$. aureus and $30^{\circ} \mathrm{C}$ for L. garvieae. Also, $1 \mathrm{ml}$ was removed from the cultures for $\mathrm{H}_{2} \mathrm{O}_{2}$ content analysis and $40 \mathrm{ml}$ for RNA extraction. Cell pellets from 6, 9 and $24 \mathrm{~h}$ cultures were resuspended in $200 \mu \mathrm{l}$ of cold Tris-EDTA buffer and then frozen at $-80^{\circ} \mathrm{C}$. The experiment was carried out in triplicate within each of three independent biological replicates, for a total of 9 samples per time point. $\mathrm{pH}$ measurements were made with the rest of the cultures.

\section{Quantitative analysis of $\mathrm{H}_{2} \mathrm{O}_{2}$ in $L$. garvieae cultures supernatant}

Hydrogen peroxide concentration was determined according to Batdorj et al. protocol [70] with slight modifications. Cells were harvested by centrifugation at $11500 \mathrm{~g}, 15^{\circ} \mathrm{C}$ for $10 \mathrm{~min}$. One hundred microliter of the sample supernatant were mixed with $100 \mu \mathrm{l}$ of 4-aminoantipyrine 4 mg.ml ${ }^{-1}$ (Sigma-Aldrich, St. Louis, Missouri, USA), $20 \mu \mathrm{l}$ of water-saturated phenol (Sigma-Aldrich, St. Louis, Missouri, USA), $750 \mu$ l of phosphate buffer $\mathrm{Na}_{2} \mathrm{HPO}_{4} /$ 
$\mathrm{NaH}_{2} \mathrm{PO}_{4} 0.1 \mathrm{M}(\mathrm{pH} 7)$ and $30 \mu \mathrm{l}$ of horseradish peroxidase type VI-A (500 U.ml ${ }^{-1}$ in sodium phosphate buffer pH 6 (Sigma-Aldrich, St. Louis, Missouri, USA). Sample was mixed by inverting the tube and OD was measured at $505 \mathrm{~nm}$. Blank was done by replacing sample by sterile medium. $\mathrm{H}_{2} \mathrm{O}_{2}$ concentration was determined using a standard curve performed with concentrations ranging from 0 to $3 \mathrm{mM}$. The minimal concentration that could be detected was $0.5 \mathrm{mM}$.

\section{RNA extraction and DNase treatments}

Cells in Tris-EDTA buffer were thawed out and $25 \mu \mathrm{l}$ of $20 \%$ SDS, $500 \mu \mathrm{l}$ of phenol $(\mathrm{pH} 4), \quad 3.5 \mu \mathrm{l}$ of $\beta$-mercaptoethanol and $600 \mathrm{mg}$ of Zirconium beads were added. The cells were broken twice in a tissue homogenizer (Precellys ${ }^{\circ}$ 24, Bertin Technologies, Montigny-le-Bretonneux, France). Then, $200 \mu \mathrm{l}$ of chloroform were added and mixed with the solution and sample was centrifuged at $11400 \mathrm{~g}$ for $20 \mathrm{~min}$ at $4{ }^{\circ} \mathrm{C}$. RNA extraction was performed using NucleoSpin RNA Midi kit (Macherey-Nagel, GmbH \& Co. KG, Düren, Germany) following the supplier's instructions. The RNA extracts were treated twice with DNAse I using an Ambion DNA-free kit following the supplier's instructions (Ambion, Inc., Austin, Texas, USA). The RNA extracts were quantified using a Nanodrop $^{\text {tm }}$ 2000C (Thermo Fisher Scientific Inc., Waltham, Massachusetts, USA).

\section{Reverse transcription and quantitative PCR}

Reverse Transcription (RT) was performed using $0.5 \mu \mathrm{g}$ of RNA twice treated with DNase, $5 \mu$ l of 10X buffer,
$2 \mu \mathrm{l}$ of $25 \mathrm{X}$ dNTP, $5 \mu \mathrm{l}$ of random primers and $2.5 \mu \mathrm{l}$ of retrotranscriptase (Applied Biosystems ${ }^{\circ}$, Life Technologies, Foster City, California, USA). The RT was done in a thermocycler (Techne ${ }^{\circ}$ Prime, Bibby Scientific, Stone, Staffordshire, UK) with the following parameters: $10 \mathrm{~min}$ at $25^{\circ} \mathrm{C}$ and $120 \mathrm{~min}$ at $37^{\circ} \mathrm{C}$.

Genes Of Interest (GOI) $\mathrm{Ct}$ were determined in quantitative PCR (qPCR) assays using $2.5 \mu \mathrm{l}$ of cDNA suspensions 10-fold diluted in RNAse-free water and $10 \mu \mathrm{l}$ of qPCR mix containing $1.25 \mu \mathrm{l}$ of each primer $(10 \mathrm{mM}$, Tables 3 and 4$), 6.25 \mu \mathrm{l}$ of qPCR Rotor Gene SybrGreen mix (Qiagen, Hilden, Germany) and $1.25 \mu \mathrm{l}$ of RNAse-free water. The qPCR was performed according to the protocol on Rotor Gene Q (Qiagen, Hilden, Germany) with the following parameters: 4 min at $94^{\circ} \mathrm{C}$, then for 35 cycles, $30 \mathrm{~s}$ at $94^{\circ} \mathrm{C}, 30 \mathrm{~s}$ at $55^{\circ} \mathrm{C}, 60 \mathrm{~s}$ at $72^{\circ} \mathrm{C}$. Each reaction was performed in triplicate within each of three independent biological replicates, for a total of 9 reactions per time point.

Primers efficiencies were determined according to a 10 -fold template dilution standard and were all ranging from $1.90(\sim 95 \%)$ to $2.293(\sim 115 \%)$ according to the following equation: Efficiency $=10^{\wedge}(-1 /$ slope of calibration curve) [71]. The primers used were previously described by others [17]. One reference gene was used for L. garvieae data: tufB encoding the elongation factor $\mathrm{Tu}$. Considering that the lag in growth phase reflects the inhibition of S. aureus by L. garvieae, we evaluated gene expression at identical time points corresponding to different population levels. Two reference genes whose expression was stable over

Table 3 Targeted Staphylococcus aureus genes

\begin{tabular}{|c|c|c|c|}
\hline Gene & Description & Category & Primers references \\
\hline$\overline{h u^{a}}$ & DNA-binding protein & Housekeeping gene & {$[74]$} \\
\hline $\operatorname{rec} A^{a}$ & Recombinase A & Housekeeping gene & {$[74]$} \\
\hline $\operatorname{agrA}$ & Accessory gene regulator $A$ & Virulence-related regulator & {$[40]$} \\
\hline$a h p F$ & Alkyl hydroperoxidase F & $\mathrm{H}_{2} \mathrm{O}_{2}$-response & {$[17]$} \\
\hline$c l p C$ & Clp proteinase C & Stress-response & {$[40]$} \\
\hline $\operatorname{cts} \mathrm{R}$ & Transcriptional repressor of stress-genes & Stress-response & {$[40]$} \\
\hline $\operatorname{cod} Y$ & Transcriptional repressor & Virulence-related regulator & {$[17]$} \\
\hline dnak & Chaperone protein DnaK & Stress-response & {$[40]$} \\
\hline hld & Deltahemolysin & Virulence-related regulator & {$[40]$} \\
\hline katA & Catalase & $\mathrm{H}_{2} \mathrm{O}_{2}$-response & {$[40]$} \\
\hline mraW & S-adenosyl methyltransferase & Cell division & {$[17]$} \\
\hline saes & Histidine protein kinase & Virulence-related regulator & {$[40]$} \\
\hline $\sec 4$ & Enterotoxin C & Enterotoxin & {$[40]$} \\
\hline $\mathrm{sel} / 2$ & Enterotoxin L & Enterotoxin & {$[40]$} \\
\hline sodA & Superoxide dismutase & $\mathrm{H}_{2} \mathrm{O}_{2}$-response & {$[40]$} \\
\hline srrA & Staphylococcal respiratory response & Virulence-related regulator & {$[40]$} \\
\hline
\end{tabular}

${ }^{\mathrm{a}}$ Reference genes 
Table 4 Targeted Lactococcus. garvieae genes

\begin{tabular}{llll}
\hline Gene & Description & Category & $\begin{array}{l}\text { Primers } \\
\text { references }\end{array}$ \\
\hline tufB & Elongation factor Tu & Housekeeping gene & {$[20]$} \\
ahpC & $\begin{array}{l}\text { Alkyl hydroxyperoxide } \\
\text { reductase }\end{array}$ & $\mathrm{H}_{2} \mathrm{O}_{2}$-degradation & {$[20]$} \\
gpx & Glutathione peroxidase & $\mathrm{H}_{2} \mathrm{O}_{2}$-degradation & {$[20]$} \\
poxB & Pyruvate oxidase & $\mathrm{H}_{2} \mathrm{O}_{2}$-synthesis & {$[20]$} \\
sodA & Superoxide dismutase & $\mathrm{H}_{2} \mathrm{O}_{2}$-synthesis & {$[20]$} \\
trxB1 & Thioredoxin reductase & $\mathrm{H}_{2} \mathrm{O}_{2}$-degradation & {$[20]$}
\end{tabular}

${ }^{\mathrm{a}}$ Reference gene

time under the different conditions were used for $S$. aureus data: housekeeping genes rec $\mathrm{A}$, encoding the recombinase $\mathrm{A}$, and $h u$, encoding a DNA-binding protein. The GOI expression was calculated according to the formula introduced by Hellemans et al. [72].

\section{Comparison of gene expression}

Differential gene expression was evaluated by comparing expression between two conditions. First, the influence of aeration on gene expression in pure culture was evaluated for $S$. aureus. Then, the influence of different strains of L. garvieae (N201, CL-1183 and Lg2) on S. aureus SA15 gene expression was observed under high or low aeration condition. Secondly, L. garvieae gene expression was compared between the different strains in co-culture with $S$. aureus SA15 under both aeration conditions. A gene was considered as differentially expressed when its expression was changed by at least a factor of 2.

\section{Statistical analyses}

Statistical analyses on microbial counts were performed using $\mathrm{R}$ software [73] by one-way analysis of variance (ANOVA) followed by Least Significant Difference (LSD) test. The gene expression statistical analyses were performed using $\mathrm{R}$ by ANOVA with Newmann-Keuls post-hoc test. Significance was declared at $P<0.05$.

\section{Additional files}

Additional file 1: Figure. S2. L. garvieae strains growth in pure culture and in coculture with S. aureus SA15, under different levels of aeration. (DOCX $116 \mathrm{~kb}$ )

Additional file 2: Table S5. Gene expression changes in S. aureus SA15 co culture with $3 \mathrm{~L}$. garvieae strains under high aeration level. (DOCX $24 \mathrm{~kb}$ )

Additional file 3: Table S6. Gene expression changes in S. aureus SA15 co culture with $3 \mathrm{~L}$. garvieae strains under low aeration level. (DOCX $24 \mathrm{~kb}$ )

Additional file 4: Table S7. Aeration induced changes in L. garvieae (N201, CL 1183 and Lg2 strains) H2O2-related gene expression in co-culture with S. aureus SA15. (DOCX $17 \mathrm{~kb})$

\section{Abbreviations}

BHI: Brain heart infusion; GOI: Gene of interest; LAB: Lactic acid bacteria; ROS: Reactive oxygen species

\section{Acknowledgements}

The authors acknowledge Mr. Mar Blanco for the gift of Lactococcus garvieae strain CL-1183, as well as Masahira Hattori and Hidetoshi Morita for the gift of Lactococcus garvieae strain Lg2 and Maryline Bornes and Kate James for English proofreading.

\section{Funding}

The authors of this work as well as the collection of data were supported by the University Clermont-Auvergne (IUT Clermont-Ferrand) and by the Institut national de la recherche agronomique (INRA). The funding bodies did not have any influence neither in the design of the study, in the analysis and the interpretation of data, nor in the writing of the manuscript.

\section{Availability of data and materials}

All data generated or analysed during this study are included in this published article [and its supplementary information files].

\section{Authors' contributions}

CQ performed the RT-qPCR, analyzed genes expression, ran statistical analyses and was a major contributor in writing the manuscript. MB contributed to cultivate the different strains, performed the quantitative analysis of $\mathrm{H}_{2} \mathrm{O}_{2}$ in $\mathrm{L}$. garvieae cultures, the RNA extraction, DNase treatment and the RT-qPCR, and was also a contributor in writing the manuscript. TS cultivated the different strains, performed the tests with added catalase, and contributed in writing the manuscript. PD helped in RT-qPCR, genes expression analysis and improvement of the manuscript. PV contributed to cultivate the different strains and to extract the RNA. ER contributed to statistical analyses. CM contributed to the adjustment of the method of quantitative analysis of $\mathrm{H}_{2} \mathrm{O}_{2}$. GG read and corrected the manuscript. SB and CD conceived the study. CD contributed to genes expression analysis and to the structuring and improvement of the manuscript. SB contributed to cultivate the different strains, performed the RNA extraction and was also a contributor in writing the manuscript. All authors read and approved the final manuscript.

Ethics approval and consent to participate

Not applicable

\section{Consent for publication}

Not applicable

\section{Competing interests}

The authors declare that they have no competing interests.

\section{Publisher's Note}

Springer Nature remains neutral with regard to jurisdictional claims in published maps and institutional affiliations.

Received: 21 December 2017 Accepted: 14 November 2018 Published online: 22 November 2018

References

1. Le Loir Y, Baron F, Gautier M. Staphylococcus aureus and food poisoning. Genet Mol Res. 2003;2:63-76.

2. Delbes-Paus C, Dorchies G, Chaabna Z, Callon C, Montel M-C. Contribution of hydrogen peroxide to the inhibition of Staphylococcus aureus by Lactococcus garvieae in interaction with raw milk microbial community. Food Microbiol. 2010;27:924-32.

3. Callon C, Duthoit F, Delbès C, Ferrand M, Le Frileux Y, De Crémoux R, et al. Stability of microbial communities in goat milk during a lactation year: molecular approaches. Syst Appl Microbiol. 2007:30:547-60.

4. Villani F, Aponte M, Blaiotta G, Mauriello G, Pepe O, Moschetti G. Detection and characterization of a bacteriocin, garviecin L1-5, produced by Lactococcus garvieae isolated from raw cow's milk. J Appl Microbiol. 2001;90:430-9.

5. Aguado-Urda M, Cutuli MT, Blanco MM, Aspiroz C, Tejedor JL, FernándezGarayzábal JF, et al. Utilization of lactose and presence of the phospho- $\beta$ galactosidase (lacG) gene in Lactococcus garvieae isolates from different sources. Int Microbiol Off J Span Soc Microbiol. 2010;13:189-93. 
6. Eldar A, Ghittino C. Lactococcus garvieae and Streptococcus iniae infections in rainbow trout Oncorhynchus mykiss: similar, but different diseases. Dis Aquat Org. 1999;36:227-31.

7. Vendrell D, Balcázar JL, Ruiz-Zarzuela I, de Blas I, Gironés O, Múzquiz JL. Lactococcus garvieae in fish: a review. Comp Immunol Microbiol Infect Dis. 2006:29:177-98.

8. Klebanoff SJ, Hillier SL, Eschenbach DA, Waltersdorph AM. Control of the microbial flora of the vagina by $\mathrm{H}_{2} \mathrm{O}_{2}$-generating lactobacilli. J Infect Dis. 1991;164:94-100

9. Gálvez A, Abriouel H, López RL, Ben ON. Bacteriocin-based strategies for food biopreservation. Int J Food Microbiol. 2007;120:51-70.

10. Charlier C, Even S, Gautier M, Le Loir Y. Acidification is not involved in the early inhibition of Staphylococcus aureus growth by Lactococcus lactis in milk. Int Dairy J. 2008;18:197-203.

11. Haines WC, Harmon LG. Effect of selected lactic acid bacteria on growth of Staphylococcus aureus and production of enterotoxin. Appl Microbiol. 1973; 25:436-41.

12. Charlier C, Cretenet M, Even S, Le Loir $Y$. Interactions between Staphylococcus aureus and lactic acid bacteria: an old story with new perspectives. Int J Food Microbiol. 2009;131:30-9.

13. Minor TE, Marth EH. Growth of Staphylococcus aureus in acidified pasteurized Milk. J Milk Food Technol. 1970;33:516-20.

14. Tatini SR, Jezeski JJ, Morris HA, Olson JC, Casman EP. Production of staphylococcal enterotoxin a in cheddar and Colby cheese. J Dairy Sci. 1971; 54:815-25.

15. Amin VM, Olson NF. Influence of catalase activity on resistance of coagulasepositive staphylococci to hydrogen peroxide. Appl Microbiol. 1968:16:267-70.

16. Alomar J, Loubiere P, Delbes C, Nouaille S, Montel MC. Effect of Lactococcus garvieae, Lactococcus lactis and Enterococcus faecalis on the behaviour of Staphylococcus aureus in microfiltered milk. Food Microbiol. 2008:25:502-8.

17. Delpech P, Bornes S, Alaterre E, Bonnet M, Gagne G, Montel M-C, et al Staphylococcus aureus transcriptomic response to inhibition by $\mathrm{H}_{2} \mathrm{O}_{2-}$ producing Lactococcus garvieae. Food Microbiol. 2015;51:163-70.

18. Fernández E, Alegría Á, Delgado S, Mayo B. Phenotypic, genetic and technological characterization of Lactococcus garvieae strains isolated from a raw milk cheese. Int Dairy J. 2010;20:142-8.

19. Baba T, Takeuchi F, Kuroda M, Yuzawa H, Aoki K, Oguchi A, et al. Genome and virulence determinants of high virulence community-acquired MRSA. Lancet. 2002;359:1819-27.

20. Delpech P, Rifa E, Ball G, Nidelet S, Dubois E, Gagne G, et al. New insights into the anti-pathogenic potential of Lactococcus garvieae against Staphylococcus aureus based on RNA sequencing profiling. Front Microbiol. 2017;8 [cited 2017 Mar 7]. Available from: http://journal.frontiersin.org/ article/10.3389/fmicb.2017.00359/abstract

21. Chiang SM, Schellhorn HE. Regulators of oxidative stress response genes in Escherichia coli and their functional conservation in bacteria. Arch Biochem Biophys. 2012;525:161-9.

22. Condon S. Responses of lactic acid bacteria to oxygen. FEMS Microbiol Lett. 1987:46:269-80.

23. Murphy MG, Condon S. Correlation of oxygen utilization and hydrogen peroxide accumulation with oxygen induced enzymes in lactobacillus plantarum cultures. Arch Microbiol. 1984;138:44-8.

24. Quatravaux S, Remize F, Bryckaert E, Colavizza D, Guzzo J. Examination of Lactobacillus plantarum lactate metabolism side effects in relation to the modulation of aeration parameters. J Appl Microbiol. 2006;101:903-12.

25. Mishra S, Imlay J. Why do bacteria use so many enzymes to scavenge hydrogen peroxide? Arch Biochem Biophys. 2012;525:145-60.

26. Margis R, Dunand C, Teixeira FK, Margis-Pinheiro M. Glutathione peroxidase family - an evolutionary overview. FEBS J. 2008;275:3959-70.

27. Holmgren A. Thioredoxin and glutaredoxin systems. J Biol Chem. 1989;264 13963-6.

28. Lu J, Holmgren A. The thioredoxin antioxidant system. Free Radic Biol Med. 2014;66:75-87.

29. Cosgrove K, Coutts G, Jonsson I-M, Tarkowski A, Kokai-Kun JF, Mond JJ, et al. Catalase (KatA) and alkyl hydroperoxide reductase (AhpC) have compensatory roles in peroxide stress resistance and are required for survival, persistence, and nasal colonization in Staphylococcus aureus. $J$ Bacteriol. 2007;189:1025-35.

30. Seaver LC, Imlay JA. Alkyl hydroperoxide reductase is the primary scavenger of endogenous hydrogen peroxide in Escherichia coli. J Bacteriol. 2001;183:7173-81.
31. Rockabrand D, Arthur T, Korinek G, Livers K, Blum P. An essential role for the Escherichia coli DnaK protein in starvation-induced thermotolerance, $\mathrm{H}_{2} \mathrm{O}_{2}$ resistance, and reductive division. J Bacteriol. 1995;177:3695-703.

32. Singh VK, Utaida S, Jackson LS, Jayaswal RK, Wilkinson BJ, Chamberlain NR. Role for dnaK locus in tolerance of multiple stresses in Staphylococcus aureus. Microbiology. 2007;153:3162-73.

33. Fiocco D, Capozzi V, Collins M, Gallone A, Hols P, Guzzo J, et al. Characterization of the CtsR stress response regulon in Lactobacillus plantarum. J Bacteriol. 2010;192:896-900.

34. Hara H, Yasuda S, Horiuchi K, Park JT. A promoter for the first nine genes of the Escherichia coli mra cluster of cell division and cell envelope biosynthesis genes, including fts/ and ftsW. J Bacteriol. 1997;179:5802-11.

35. Srinivasan V, Sawant AA, Gillespie BE, Headrick SJ, Ceasaris L, Oliver SP. Prevalence of enterotoxin and toxic shock syndrome toxin genes in Staphylococcus aureus isolated from milk of cows with mastitis. Foodborne Pathog Dis. 2006;3:274-83

36. Cha JO, Lee JK, Jung YH, Yoo Jl, Park YK, Kim BS, et al. Molecular analysis of Staphylococcus aureus isolates associated with staphylococcal food poisoning in South Korea. J Appl Microbiol. 2006;101:864-71.

37. Chiang Y-C, Liao W-W, Fan C-M, Pai W-Y, Chiou C-S, Tsen H-Y. PCR detection of staphylococcal enterotoxins (SEs) N, O, P, Q, R, U, and survey of SE types in Staphylococcus aureus isolates from food-poisoning cases in Taiwan. Int J Food Microbiol. 2008;121:66-73.

38. Kérouanton A, Hennekinne JA, Letertre C, Petit L, Chesneau O, Brisabois A, et al. Characterization of Staphylococcus aureus strains associated with food poisoning outbreaks in France. Int J Food Microbiol. 2007;115:369-75.

39. Wieneke AA, Roberts D, Gilbert RJ. Staphylococcal food poisoning in the United Kingdom, 1969-90. Epidemiol Infect. 1993;110:519-31.

40. Cretenet M, Nouaille $S$, Thouin J, Rault L, Stenz L, François P, et al. Staphylococcus aureus virulence and metabolism are dramatically affected by Lactococcus lactis in cheese matrix. Environ Microbiol Rep. 2011;3:340-51.

41. Dassy B, Hogan T, Foster TJ, Fournier JM. Involvement of the accessory gene regulator (agr) in expression of type 5 capsular polysaccharide by Staphylococcus aureus. J Gen Microbiol. 1993;139(Pt 6):1301-6.

42. Gaskill ME, Khan SA. Regulation of the enterotoxin B gene in Staphylococcus aureus. J Biol Chem. 1988;263:6276-80.

43. Janzon $L$, Arvidson S. The role of the delta-lysin gene $(h / d)$ in the regulation of virulence genes by the accessory gene regulator (agr) in Staphylococcus aureus. EMBO J. 1990:9:1391-9.

44. Peng HL, Novick RP, Kreiswirth B, Kornblum J, Schlievert P. Cloning, characterization, and sequencing of an accessory gene regulator (agr) in Staphylococcus aureus. J Bacteriol. 1988;170:4365-72.

45. Regassa LB, Couch JL, Betley MJ. Steady-state staphylococcal enterotoxin type $\mathrm{C}$ mRNA is affected by a product of the accessory gene regulator (agr) and by glucose. Infect Immun. 1991;59:955-62.

46. Liang X, Yu C, Sun J, Liu H, Landwehr C, Holmes D, et al. Inactivation of a two-component signal transduction system, SaeRS, eliminates adherence and attenuates virulence of Staphylococcus aureus. Infect Immun. 2006;74: 4655-65.

47. Giraudo AT, Rampone H, Calzolari A, Nagel R. Phenotypic characterization and virulence of a sae $e^{-}$agr $^{-}$mutant of Staphylococcus aureus. Can J Microbiol. 1996;42:120-3.

48. Goerke C, Fluckiger U, Steinhuber A, Bisanzio V, Ulrich M, Bischoff M, et al. Role of Staphylococcus aureus global regulators sae and $\sigma^{B}$ in virulence gene expression during device-related infection. Infect Immun. 2005;73: 3415-21.

49. Rogasch K, Rühmling V, Pané-Farré J, Höper D, Weinberg C, Fuchs S, et al. Influence of the two-component system SaeRS on global gene expression in two different Staphylococcus aureus strains. J Bacteriol. 2006;188:7742-58.

50. Steinhuber A, Goerke C, Bayer MG, Döring G, Wolz C. Molecular architecture of the regulatory locus sae of Staphylococcus aureus and its impact on expression of virulence factors. J Bacteriol. 2003;185:6278-86.

51. Fuchs S, Pané-Farré J, Kohler C, Hecker M, Engelmann S. Anaerobic gene expression in Staphylococcus aureus. J Bacteriol. 2007;189:4275-89.

52. Ulrich M, Bastian M, Cramton SE, Ziegler K, Pragman AA, Bragonzi A, et al. The staphylococcal respiratory response regulator SrrAB induces ica gene transcription and polysaccharide intercellular adhesin expression, protecting Staphylococcus aureus from neutrophil killing under anaerobic growth conditions. Mol Microbiol. 2007;65:1276-87. 
53. Chang W, Small DA, Toghrol F, Bentley WE. Global transcriptome analysis of Staphylococcus aureus response to hydrogen peroxide. J Bacteriol. 2006;188: 1648-59.

54. Pragman AA, Yarwood JM, Tripp TJ, Schlievert PM. Characterization of virulence factor regulation by SrrAB, a two-component system in Staphylococcus aureus. J Bacteriol. 2004;186:2430-8.

55. Yarwood JM, McCormick JK, Schlievert PM. Identification of a novel twocomponent regulatory system that acts in global regulation of virulence factors ofStaphylococcus aureus. J Bacteriol. 2001;183:1113-23.

56. Majerczyk CD, Sadykov MR, Luong TT, Lee C, Somerville GA, Sonenshein AL. Staphylococcus aureus CodY negatively regulates virulence gene expression. J Bacteriol. 2008;190:2257-65.

57. Dijkstra AR, Alkema W, Starrenburg MJ, Hugenholtz J, van Hijum SA, Bron PA. Fermentation-induced variation in heat and oxidative stress phenotypes of Lactococcus lactis MG1363 reveals transcriptome signatures for robustness. Microb Cell Factories. 2014;13:148.

58. Ocaña VS, Holgado AAP de R, Nader-Macías ME. Growth inhibition of Staphylococcus aureus by $\mathrm{H}_{2} \mathrm{O}_{2}$ - producing Lactobacillus paracasei subsp. paracasei isolated from the human vagina. FEMS Immunol Med Microbiol. 1999;23:87-92. Available from: http://onlinelibrary.wiley.com/doi/10.1111/j. 1574-695X.1999.tb01227.x/abstract:jsessionid= 3D0D6339EEB88C5073FB7F86C2639DCE.f04t02

59. Marty-Teysset C, de la Torre F, Garel J. Increased production of hydrogen peroxide by Lactobacillus delbrueckii subsp bulgaricus upon aeration: involvement of an NADH oxidase in oxidative stress. Appl Environ Microbiol. 2000;66:262-7.

60. Morita H, Toh H, Oshima K, Yoshizaki M, Kawanishi M, Nakaya K, et al. Complete genome sequence and comparative analysis of the fish pathogen Lactococcus garvieae. PLOS ONE. 2011;6 [cited 2016 Feb 1]. Available from: http://www.ncbi.nlm.nih.gov/pmc/articles/PMC3150408/

61. Mashruwala AA, Boyd JM. The Staphylococcus aureus srrAB Regulatory system modulates hydrogen peroxide resistance factors, which imparts protection to aconitase during aerobic growth. PLoS ONE. 2017;12 Available from: https://www.ncbi.nlm.nih.gov/pmc/articles/PMC5242492/.

62. Chatterjee I, Becker P, Grundmeier M, Bischoff M, Somerville GA, Peters $\mathrm{G}$, et al. Staphylococcus aureus ClpC is required for stress resistance, aconitase activity, growth recovery, and death. J Bacteriol. 2005;187: 4488-96.

63. Krüger $E$, Völker $U$, Hecker M. Stress induction of $c l p C$ in Bacillus subtilis and its involvement in stress tolerance. J Bacteriol. 1994;176:3360-7.

64. Singh P, Panda D. FtsZ inhibition: a promising approach for antistaphylococcal therapy. Drug News Perspect. 2010;23:295.

65. Kim B-M, Choi H-Y, Kim G-W, Zheng C-J, Kim Y-H, Kim W-G. Madurahydroxylactone, an inhibitor of Staphylococcus aureus FtsZ from Nonomuraea sp. AN100570. J Microbiol Biotechnol. 2017;27:1994-8.

66. Oogai Y, Kawada-Matsuo M, Komatsuzawa H. Staphylococcus aureus SrrAB affects susceptibility to hydrogen peroxide and co-existence with Streptococcus sanguinis. PLoS ONE. 2016;11 Available from: https://www. ncbi.nlm.nih.gov/pmc/articles/PMC4956065/.

67. Ledala N, Zhang B, Seravalli J, Powers R, Somerville GA. Influence of iron andaeration on Staphylococcus aureus growth, metabolism, and transcription. J Bacteriol. 2014;196(12):2178-89.

68. Queck SY, Jameson-Lee M, Villaruz AE, Bach T-HL, Khan BA, Sturdevant DE, et al. RNAll-independent target gene control by the agr quorum-sensing system: insight into the evolution of virulence regulation in Staphylococcus aureus. Mol Cell. 2008;32:150-8.

69. Tosukhowong A, Zendo T, Visessanguan W, Roytrakul S, Pumpuang L, Jaresitthikunchai J, et al. Garvieacin Q, a novel class II Bacteriocin from Lactococcus garvieae BCC 43578. Appl Environ Microbiol. 2012;78: 1619-23.

70. Batdorj B, Trinetta V, Dalgalarrondo M, Prévost $H$, Dousset $X$, Ivanova I, et al. Isolation, taxonomic identification and hydrogen peroxide production by Lactobacillus delbrueckii subsp. lactis T31, isolated from Mongolian yoghurt: inhibitory activity on food-borne pathogens. J. Appl. Microbiol. 2007;103: 584-93

71. Rasmussen R. Quantification on the LightCycler. In: Meuer PD, Med S, Wittwer PDC, Nakagawara DK-I, editors. Rapid Cycle Real-Time PCR. Springer Berlin Heidelberg; 2001. p. 21-34 [cited 2016 Feb 3]. Available from: http://link.springer.com/chapter/10.1007/978-3-642-59524-0_3

72. Hellemans J, Mortier G, De Paepe A, Speleman F, Vandesompele J, qBase relative quantification framework and software for management and automated analysis of real-time quantitative PCR data. Genome Biol. 2007:8:R19.

73. R Core Team. R. A language and environment for statistical computing. Vienna: R Foundation for Statistical Computing; 2014. Available from: http://www.R-project.org

74. Valihrach L, Demnerova K. Impact of normalization method on experimental outcome using RT-qPCR in Staphylococcus aureus. J Microbiol Methods. 2012;90:214-6.
Ready to submit your research? Choose BMC and benefit from:

- fast, convenient online submission

- thorough peer review by experienced researchers in your field

- rapid publication on acceptance

- support for research data, including large and complex data types

- gold Open Access which fosters wider collaboration and increased citations

- maximum visibility for your research: over $100 \mathrm{M}$ website views per year

At $\mathrm{BMC}$, research is always in progress.

Learn more biomedcentral.com/submissions 